\title{
Self-Efficacy and Civic Engagement in Undergraduate Students: Empirical Results of a Service Learning Program in Thailand
}

\author{
Prasart Nuangchalerm \\ Faculty of Education \\ Mahasarakham University \\ Mahasarakham 44000 THAILAND \\ prasart.n@msu.ac.th
}

\begin{abstract}
The environmental and cultural problems in Thailand are large and widely distributed. To address these problems, public awareness must be raised and all sectors of society must assume their civic responsibilities to assist in sustaining both our environment and the local culture. This study sought to engage undergraduate students in civic engagement projects in order to enhance their self-efficacy to address such problems through service learning experiences. One hundred and ninety six undergraduate students participated in a general education course on civic education during the first semester of 2012. This course provided students the opportunity to explore theoretical aspects of citizenship as well as the opportunity to practice community service. Such community service allows the students to experience and learn how the community members live. Data was collected by a variety of methods; selfefficacy questionnaires, student reports, journal writing and reflections, and interviews. Findings revealed that the students had high levels of self-efficacy and increased their levels of civic engagement through the community service conducted.
\end{abstract}

Index terms: service learning, community service, self-efficacy, civic engagement

\section{INTRODUCTION}

The crisis in Thailand related to environmental degradation and natural resources depletion calls for involvement by all sectors, especially those problems caused by human practices. Global trends suggest a more holistic view of such problems be taken. This directly relates to the notion of citizenship. Such problems are not only related to the environment but also to cultural attitudes which facilitate such practices. The indigenous knowledge that is embedded within each community is sustained by a process of learning from generation to generation. Yet solutions of such environmental problems, through sustainable development, requires educational practices be implemented. One such practice is the introduction of service learning education. Such means of education are essential in attempts to improve and shape our society for sustainable development.

\section{Service Learning}

Higher education was founded with a civic mission that addresses important issues affecting the community, the nation, and the world. Higher education plays a significant role in shaping our society. Instructional practices at this level for the most part emphasize theory. Most studies, however, indicate that more than simply theoretical knowledge is needed to better educate students. Higher education should be guided by the results of assessment ${ }^{1}$. Such assessment results should guide actions which have a positive societal impact. Students need the necessary skills and knowledge, drawn from real life experiences, as well as from pragmatic frameworks ${ }^{2}$. Students should be exposed to learning through user-centered, 
community-based, and practical-based contexts. We need to encourage our children to gain a sense of autonomy and control and help them realize the link between their efforts and society's ability to address environmental issues.

The term service learning is an educational methodology that combines community service with explicit academic learning objectives, community work, and deliberate reflection ${ }^{3,4}$. It engages students within the local community through completion of hands-on projects while enhancing civic engagement ${ }^{5,6,7}$.

The notion of service learning is not new in education. It has been described through experiential learning theory ${ }^{8}$. It provides a model of the learning process as well as a model of adult development. Service learning emphasizes socially responsible and responsive instructional practices. It also can influence authentic learning outcomes, critical reflection, and civic engagement ${ }^{9}$. This approach helps students develop as leaders, able to address the widespread social and environmental problems, and to prepare students to be good citizens in a rapidly changing world ${ }^{10}$.

Service learning is a student-centered pedagogy that connects authentic, meaningful service to communities with academic rigor and reflection learned through systemic pedagogical practices ${ }^{11}$. It also allows students the opportunities to link academic theories with practical applications to address important needs of the community.

\section{Self-Efficacy}

The expectancy for classroom success, or self-efficacy, involves beliefs about how well one can successfully perform academic activities and enhance cognitive skills. It is directly associated with behavioral, cognitive, and motivational engagement in academic practices ${ }^{16}$. Self-efficacy influences the learning strategies and intrinsic motivation ${ }^{17,18}$. If students have all of the above, and perceive it important, higher cognitive achievement is attained ${ }^{19}$. At this point, students should be aware of self-efficacy in terms of its value and it being positively linked to teaching and learning.

Cone studied the effect of service learning on enhancing self-efficacy beliefs of preservice elementary teachers ${ }^{12,13,14}$. The findings indicated that service learning significantly influenced pre-service teachers and their expectancy in achieving equitable teaching and learning outcomes. Bandura explained the role of self-efficacy and how it is linked to educational outcomes 'as a situation-specific construct concerned with how an individual judges his/her ability to organize and successfully performed in prospective situations ${ }^{15}$. Not only is self-efficacy enhanced in the context of service learning, but civic engagement is as well.

This study explored student self-efficacy and civic engagement when performing service learning. The results will be used for pedagogical management and engagements of students to be better citizens.

\section{METHODOLOGY}

A general education course focusing on civic education was offered fall semester 2012 with the goal of having students gain a greater awareness of proper citizenship. One hundred ninety six of first and second year undergraduate students enrolled and participated in this study which was housed in a course which had the students meet 2 hours each week for 15 weeks. The course had two parts: theoretical enrichment and practical skills through projectbased construction. The instructional process provided them a background about civic engagement, citizenship, moral education, and way of life of the community located not far 
from university. This course allowed them to understand how education influences development of the community. This effort incorporated three instructional processes:

- Preparation: the first instructional process allowed students to understand how education plays an important role in terms of community development, how to be a good citizen based on the concept of good democracy, a good citizen, and a good community. The students spent 7 weeks in lecture-based and group-based learning environments where they discussed how to sustain a community in a continuously changing world. The students delegated responsibilities for the various project aspects and investigated the target community. Community members were interviewed and photographed.

- Action: the second instructional process had students work with community members and peers by conducting a project. Each group consisted of 10-15 students. The students communicated their efforts through video, journal writing, and report. The effort was undertaken at different locations including: a primary school, secondary school, temple, university, and a village. Each group recorded and assessed information gathered through: interviewing, observing, making questionnaires, and videotape recordings. The outcome of this process served as the basis for indentifying the needs of the community.

- Reflection: the third instructional process was conducted when the students were back in the classroom. Presentations and reflection by whole class were undertaken. Each group presented what they did and how the project attempted to attain the goal of study. All group members prepared their presentations focusing on project-based construction and community service. Video recordings, questionnaires, reports, and presentations were important evidences to indicate success in service learning.

Following completion of these three processes, participants were asked to express what they had learned through service learning in both classroom and community portions of study. A Likert's five-point rating scale was used to assess the level of self-efficacy by each student. Each respondent was asked to rate each item on the respective scales. They could rate each item on a 1-to-5 response scale where; $1=$ strongly disagree, $2=$ disagree, $3=$ undecided, $4=$ agree, and $5=$ strongly agree. Data were analyzed by mean and standard deviation. Data were recorded; statistic values were calculated and interpreted by using the criteria as shown in table 1.

TABLE 1

MEAN AND INTERPRETATION OF STUDENTS' SELF-EFFICACY

\begin{tabular}{c|c}
\hline Mean & Interpretation \\
\hline $4.51-5.00$ & Highest \\
$3.51-4.50$ & High \\
$2.51-3.50$ & Medium \\
$1.51-2.50$ & Low \\
$1.00-1.50$ & Lowest \\
\hline
\end{tabular}

Participants expressed their understanding of the concept of civic education and community service. They employed various kind of presentations i.e., powerpoint, poster, video, and report for concluding about what they had learned by project-based activity. Reflective writing was also employed to allow examination of the impact on citizenship. 


\section{FINDINGS}

\section{Self-efficacy}

The study focused on how the students rated their self-efficacy after exposure to a service learning project. All students scored at a high level as illustrated in Table 2.

TABLE 2

STUDENTS' SELF-EFFICACY

\begin{tabular}{l|c|c|c}
\hline \multicolumn{1}{c|}{ Item } & Mean & SD & $\begin{array}{c}\text { Level of } \\
\text { self-efficacy }\end{array}$ \\
\hline I can help myself & 4.36 & 0.64 & High \\
\hline I can help others & 3.87 & 0.65 & High \\
\hline I can do by my best for social activities & 4.01 & 0.70 & High \\
\hline I feel good in at what time I do something for society & 4.39 & 0.63 & High \\
\hline I am ready to work with others & 4.30 & 0.65 & High \\
\hline I eager to have activities with others & 4.20 & 0.78 & High \\
\hline I am very popular in the group & 3.68 & 0.83 & High \\
\hline I can do more than those I think & 3.80 & 0.80 & High \\
\hline I have responsibility to success my assigned & 4.20 & 0.80 & High \\
\hline I am very proudly with work in which do with others & 4.42 & 0.83 & High \\
\hline I am key person when teacher give an assignment & 3.61 & 0.96 & High \\
\hline I am ready to have assignment & 4.41 & 0.95 & High \\
\hline I happy with assignment & 4.32 & 1.06 & High \\
\hline Nothing to do that I can do, even if ignore & 4.27 & 1.15 & High \\
\hline I am a friendly person & 4.20 & 1.27 & High \\
\hline I love to do public activities & 4.35 & 1.24 & High \\
\hline I have competence to do social activities & 4.45 & 1.28 & High \\
\hline I do anything by social rules & 4.30 & 1.41 & High \\
\hline I was selected by friends adding into group & 4.00 & 1.54 & High \\
\hline
\end{tabular}

The students had a high level of self-efficacy for all items. The students indicated that often times they viewed themselves as both leader and follower i.e., "I am a key person when the teacher gives an assignment, I am very popular in the group, I can do more than those I think".

\section{Civic engagement}

Students shared their opinions on how to be good citizens and on how and when civic engagement should be incorporated into community service. The service learning led them to enhance a character dimension that altered their understanding of moral development and team-based learning. The course also permitted students to understand the ways of life in a community which would have been difficult to learn through classroom hours. Students spent time in talking with others through facebook, e-mail, chat, mobile phone, meeting, and etc. Effective communication assisted them in reaching the goal of community familiarization and partnership. It was sometimes difficult due to the many scheduling conflicts. However, the process of communication led them to talk with others and thus complete the assignment. Students learned how to communicate effectively; think positively and how to succeed with the project. The findings can be shown as follows: 
"The class not only teaches me on theory, but also outdoors activities allowed me to have new friends. I have learned how to live with others based on moral and ethical decisionmaking"

"Group activities meant to me in terms of human values, life is good when we do something with others. Respect in human right and social rules is summarized course"

"This course teach dare to do, life learning, working, leadership, no fear to think and do, and no waste time to think than those to do"

"Life skills and knowledge are much more than those the past because I have learn how to share happiness to people around me"

"Students have learned how to be a good citizen by implementing a community service, group-based learning and problem-based learning help us to have decision-making through democratic way"

"I have learned to serve community by transferring understanding and ideas through group meeting"

"I feel better when community service let me understand of human value and virtue that community gives to me"

The outcome of this study was not only an assessment of enhanced understanding about civic education, but it also led students to an enhanced understanding of learning styles and their significance. Learning to be a better citizen requires students learn by both mind-on and hands-on experiences. Knowledge must be obtained through engagement with the community.

\section{DISCUSSION}

The findings of this research reinforce the benefits of teaching and learning through informal education and how the university might better support communities. The framework for exploring problems was based on garnering community perceptions through participation, while the university contributed its skills in facilitating community engagement. The research has potential for building university-community support for practical action. Findings demonstrated increased levels of student's self-efficacy, service learning can facilitate student engagement in community service, and better understanding of the philosophy of higher education. This research can help us to meet the requirements in both community and other governmental organizations units which need to solve problems. Such a process could be used by engaged community stakeholders, giving them a sense of ownership of the practical outcomes ${ }^{20}$. Community service by students enrolled in institutions of higher learning should be incorporated in seeking political and pedagogical solutions that will change community learning ${ }^{21}$.

The role of university that engaged scholarship and service learning in particular, plays in linking students' academic learning with practical experiences in the community. Also, making a connection with other organizations to fulfill philosophy of sufficiency economy as crucial criteria, village members can take a role to be good learners. They know what are really needs to develop skills and what university have to support in terms of scholars and 
related knowledge ${ }^{22,23}$. Integrating community service into the university curriculum involves a pedagogical strategy and service learning will help students to learn civic engagement. Service learning provides real world skills and experiences that the traditional classroom setting cannot. The students sustain and increase social participation through service learning, love to learn community, satisfy to learning activities, and incubate expected citizens.

The reflection to the study help students share their opinions about community service, service learning is an effective learning in which promote understanding and attributes development. Through reflection journals, students can share understanding of moral development, an enhanced awareness of the team-based responsibilities, and also civic engagement ${ }^{24},{ }^{25}$. Reflection was a critical element throughout the service learning process incorporating past experiences into the present situation and stimulates students to make meaningful learning of both the academic and service learning experiences. The reflection is an the final step of service learning is an effective way to understand the development of virtues in student ways. According to the concept of $21^{\text {st }}$ century citizens' preparation in which promote global awareness based on critical thinking and problem-solving, students can learn through reflection in of what they think and what they do.

\section{REFERENCES}

1 Astin, A.W. and Antonio, A.L. (2012). Assessment for excellence. $2^{\text {nd }}$ ed. Maryland: Rowman \& Littlefield Publishers.

2 Blewitt, J. and Cullingford, C. (eds). (2004). The sustainability curriculum: the challenge for higher education. London: Earthscan.

3 Ellis, M.M. (2013). Successful community college transfer students speak out. Community College Journal of Research and Practice. 37(2): 73-84.

4 Benneworth, P. and Charles, D. (2013). University-community engagement in the wider policy environment. In Benneworth, P. (editor). University engagement with socially excluded communities. London: Springer Dordrecht Heidelberg. pp 223-241.

5 Benneworth, P. and Humphrey, L. (2013). Universities' perspectives on community engagement. In Benneworth, P. (editor). University engagement with socially excluded communities. London: Springer Dordrecht Heidelberg. pp 165-187.

6 Clevenger, C.M. and Ozbek, M.E. (2013). Teaching sustainability through servicelearning in construction education. International Journal of Construction Education and Research. 9(1): 3-18.

7 Hart and Aumann, K. (2013). Challenging inequalities through community-university partnerships. In Benneworth, P. (editor). University engagement with socially excluded communities. London: Springer Dordrecht Heidelberg. pp 47-65.

8 Kolb, A.Y. and Kolb, D.A. (2005). Learning styles and learning spaces: enhancing experiential learning in higher education. Academy of Management Learning \& Education. 4(2): 193-212.

9 Galvan, C. and Parker, M. (2011). Investigating the reciprocal nature of service-learning in physical education teacher education. Journal of Experiential Education. 34(1): 5570.

10 Boyer, E.L. (1990). In Search of Community. Paper presented at the Annual Meeting of the American Council on Education. Washington, DC, January 18, 1990.

11 Eyler, J. and Giles, D.E.,Jr. (1999). Where's the learning in service-learning? JosseyBass higher and adult education series. California: Jossey-Bass. 
12 Cone, N. (2009a). A bridge to developing efficacious science teachers of all students: community-based service-learning supplemented with explicit discussions and activities about diversity. Journal of Science Teacher Education. 20: 265-383.

13 Cone, N. (2009b). Community-based service-learning as a source of personal selfefficacy: preparing preservice elementary teachers to teach science for diversity. School Science and Mathematics. 109(1): 20-30.

14 Cone, N. (2009c). Preservice elementary teachers' self-efficacy beliefs about equitable science teaching: does service learning make a difference. Journal of Elementary Science Education. 21(2): 25-34.

15 Bandura, A. (1997). Exercise of personal and collective efficacy in changing societies. In Bandura, A. (editor). Self-efficacy in the Changing Societies. Cambridge: Cambridge University press.pp 1-45.

16 Linnenbrink, E.A. and Pintrich, P.R. (2003). The role of self-efficacy beliefs in student engagement and learning in the classroom. Reading \& Writing Quarterly: Overcoming Learning Difficulties. 19(2): 119-137.

17 Bandura, A. (1993). Perceived self-efficacy in cognitive development and functioning. Educational Psychologist. 28(2): 117-148.

18 Usher, E.L. and Pajares, F. (2006). Sources of academic and self-regulatory efficacy beliefs of entering middle school students. Contemporary Educational Psychology. 31(2): 125-141.

19 Wigfield, A. and Eccles, J.S. (2000). Expectancy-value theory of achievement motivation. Contemporary Educational Psychology. 25(1): 68-81.

20 Webb, T. and Burgin, S. (2009). Engaged service learning: Implications for higher education. Journal of Learning Design. 3(1): 41-56.

21 Butin, D. W. (2006). Disciplining service learning: Institutionalization and the case for community studies. International Journal of Teaching and Learning in Higher Education. 18(1): 57-64.

22 Berle, D. (2006). Incremental integration: A successful service-learning strategy. International Journal of Teaching and Learning in Higher Education. 18(1): 43-48.

23 Deal, C. (2006). Learning with conviction: Service learning, social documentary, and transformative research. InterActions: UCLA Journal of Education and Information Studies. 2(1): 1-16.

24 Fox, J., Jones, K., Machtmes, K. and Cater, M. (2012). A qualitative examination of a character development service learning project and its impact on internalizing virtues in college students. Journal for Civic Commitment. 19: 1-18.

25 Littlepage, L., Gazley, B. and Bennett, T.A. (2012). Service learning from the supply side community capacity to engage students. Nonprofit Management \& Leadership. 22(3): 305-320. 